A. B. Мудла, аспірант, кафедри економічної теорії та конкурентної політики, Київский начіональний торговельно-економічний університет, м. Київ

DOI: $10.32702 / 2306-6814.2018 .23 .94$

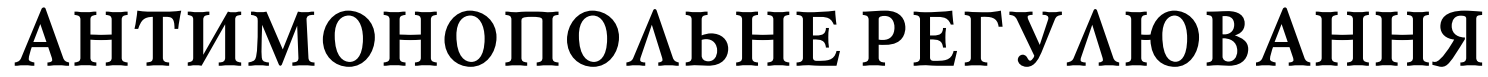

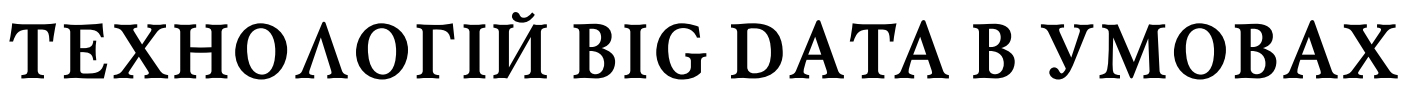 ЦИФРОВОÏ ЕКОНОМІКИ
}

\author{
D. Mudla, \\ Post-graduate student, Department of Economic Theory and Competition Policy, \\ Kyiv National Trade and Economic University, Kyiv
}

\section{ANTITRUST REGULATION OF BIG DATA TECHNOLOGIES IN THE DIGITAL ECONOMY}

Устатті досліджено теоретичні аспекти формування понять "цифрова економіка" і технологіі Big Data (Великі Дані). Досліджено вплив технологій Big Data на формування конкурентних переваг національної і світової економіки. Визначено, що цифрові платформи, алгоритми, Великі Дані - це нова реальність цифрової економіки глобального характеру, а основні гравці ринку цифрових платформ використовують інноваційне середовище для забезпечення домінуючого становища на ринку. Встановлено, що використання компаніями передових технологій дозволяє нав 'язувати споживачам неправомірні умови, розширювати ринкову владу, підвищувати ціни і закривати ринки для потенційних конкурентів. Зроблено висновок, що нова модель ринкової конкуренції в умовах цифрової економіки вимагає використання якісно нових інструментів антимонопольного регулювання та вдосконалення існуючих способів захисту конкуренції. Обгрунтовано, що держава повинна сприяти розвиткуцифрової економіки та формувати нову технологічну структурудля забезпечення конкурентних переваг, враховуючи глобальні тенденції антимонопольного регулювання цифрової економіки.

The article investigates the theoretical aspects of the formation of the concepts of "digital economy" and the technology of Big Data. The influence of Big Data technologies on the formation of competitive advantages of the national and world economy has been investigated. It is determined that digital platforms, algorithms, Big Data are a new reality of the digitaleconomy of global character, and the major players in the digital platform market use an innovative environment to secure a dominant position in the market. It is established that the use of advanced technologies by companies allows imposing unlawful conditions on the consumers, expanding market power, raising prices and closing markets for potential competitors.

It is substantiated that knowledge about Big Data can become an important source of market power, especially when such data can be used as barriers. The speed of the acquisition and use of personal data helps companies to gain a significant advantage and market power. It has been found that, in the context of the production of information products, the definition of costs based on the price is unacceptable, since the marginal costs per unit of the product are close to zero. Many products and services offered on the e-commerce markets have a zero price, but this does not mean you can get a product or service free of charge because money in this market is not the only commodity that is valuable for exchange.

It is determined that the competitive process of a new economy is dynamic and universal, unlike physical markets. In the digital economy we have a fundamental difference regarding the protection of economic competition in comparison with physical markets. 
It is concluded that the new model of market competition in the digital economy requires the use of qualitatively new instruments of antimonopoly regulation and improvement of existing methods of competition protection. The state should promote the development of the digital economy and form a new technological structure to ensure competitive advantages. It should also take into account the global trends of antitrust regulation under the conditions of digital economics.

Ключові слова: цифрова економіка, Big Data (Великі Дані), конкуренція, антимонопольне регулюВання. Key words: digital economy, big data, competition, antitrust regulation.

\section{ПОСТАНОВКА ПРОБАЕМИ}

В умовах формування інфрормаційного суспільства в різних галузях економіки створюється і накопичується велика кількість даних. Зростає потік електронної інфрормації, з'являються нові інорормаційні та комунікаційні технології, з розвитком яких зростає потреба в інфрормаційних продуктах і послугах. Щоб задовольнити вимоги споживачів, підприємства накопичують і аналізують велику кількість даних з різних джерел. Накопичена інформація має стратегічне значення для прийняття управлінських рішень. Зростання потреб бізнесу в обробці і накопичені великого обсягу інформації, наявність технічних засобів, що здійснюють оперативне опрацювання таких даних, призвів до появи перспективного напряму специфрічних технологій Big Data (Великі Дані). Учасники економічної діяльності все частіше генерують нові ринки, намагаючись отримати повну монополію. Концентрація великої кількості даних в обмеженої кількості учасників ринку призводить до зростання нерівності і створення монополістичних та олігополістичних кластерів. Без втручання держави в становлення і розвиток цифрової економіки, абсолютна монополія може стати звичним явищем.

\section{АНА $\Lambda$ IЗ ОСТАНHIX АОС $А$ АЖЕНЬ І ПУБ $А$ АЦІЙ}

Теоретичні аспекти цифрової економіки досліджуються і дискутуються в працях багатьох вітчизняних і зарубіжних вчених і дослідників: В. Апалькова, Д. Белла, С. Веретюк, Х. Екбіа, Л.Жукова, К. Маскус, С. Коляденко, Л. Кіт, Н . Негропонте, Б. Нарде, Л. Саммерс, Д. Стігліц, Д. Тапскотта, Е. Тоффрлер, Дж. Фон Нейман, С. Хантінгтон та ін. Особливості фрормування цифррових технологій Big Data викладено в працях таких вітчизняних і зарубіжних вчених та практиків: Є. Гнітецький, О. Зибарева, В. Серьогін, В. Хаханов, П. Хофрманн. В сучасних умовах цифрова економіка, технології Big Data та їх регулювання ще недостатньо проаналізовані і вивчені, тому виникає потреба в їх подальших наукових дослідженнях в умовах глобального інтенсивного розвитку суспільства.

\section{META CTATTI}

Розкрити теоретичні аспекти фрормування цифрової економіки, технологій Big Data (Великі Дані) в контексті ії̈ впливу на конкурентоспроможність. Визначення необхідності формування нових підходів до антимонопольного регулювання в умовах цифрової економіки.

\section{ВИК ААА ОСНОВНОГО МАТЕРІААУ АОС $\triangle$ IАЖЕННЯ}

Ідея "цифрової економіки" вперше була висвітлена в теорії Деніела Белла [1, с. 180-182].

Цифрова економіка (Digital economy) - це економіка, заснована на цифрових комп'ютерних технологіях. Цифррову економіку іноді називають інтернет-економікою, новою економікою, або веб-економікою. Під цифровою економікою розуміють виробництво, продаж та поставку продукції через комп'ютерні мережі [2].

Термін "цифрова економіка" в 1995 році застосував канадський вчений Дон Тапскотт, стверджуючи, що цифрова економіка фоомується на застосуванні цифрових технологій [3]. Серед найважливіших наслідків цифровізації економіки Дон Тапскотт, звертаючись до теорії фрірми Рональда Коуза [1, с. 182-183], називає можливість радикального зниження трансакційних витрат, перш за все, видатків на пошук інформації та укладання договорів, і як наслідок появи нових форм бізнесу, без посередників, з прямою взаємодією споживачів і постачальників, переміщенням бізнесу з традиційних фоом в інтернет простір.

Американський програміст Ніколас Негропонте сорормував концепцію цифрової економіки як "перехід від обробки атомів до обробки "бітів" [4]. Томас Месенбург виділив основні складові концепції "Цифрова економіка": підтримуюча інфрраструктура (апаратне і програмне забезпечення, телекомунікації, мережі та ін.); електронний бізнес або e-business (ведення господарської діяльності і будь - яких інших бізнес-процесів через комп'ютерні мережі); електронна комерція або еcommerce (дистрибуція товарів через Інтернет) [5].

У класичному розумінні "цифрова економіка" - це діяльність, в якій ключовими фракторами (засобами) ви- 
робництва $€$ цифрові дані та їх використання, що дозволяє суттєво підвищити ефективність / продуктивність в різних видах економічної діяльності. Конкретизуючи поняття, "цифровою економікою" називають економіку, яка застосовує (споживає) цифрові технології і сервіси [6].

Л. Жукова зазначає, що цифрова економіка є складовою частиною економіки, в якій домінують знання суб'єктів і нематеріальне виробництво, тобто основний показник під час визначення інформаційного суспільства. Розвиток цифрової економіки та формування інфрормаційного суспільства є глобальною тенденцією, сприяє стрімкому розвитку інновацій, технологій, залежить від людського капіталу та може суттєво прискорити розвиток кожної галузі та економіки в цілому [7, c. 7-11].

Економіку, що активно абсорбує і використовує цифррові технології, називають "цифровою". Вона найважливіший двигун інновацій, конкурентоспроможності та економічного розвитку в країні, тому Європейський Союз вважає її всебічний розвиток ключовим напрямком свого бізнес-середовища в стратегіях майбутнього, на думку В. Апалькова [8, с. 9-18].

С. Коляденко зазначає, що цифрова економіка це економіка, заснована на виробництві електронних товарів і сервісів високотехнологічними бізнес-структурами і дистрибуції цієї продукції за допомогою електронної комерції [9, с. 105-112].

Л. Кіт визначає, що цифрова економіка - це трансфрормація всіх сорер економіки завдяки перенесенню інфрормаційних ресурсів та знань на комп'ютерну платфрорму з ціллю їх подальшого використання (виключно там, де це можливо) на цій платформі, та $є$ складовою мережевої економіки [10, с. 187-194].

Цифрова економіка швидкими темпами розвивається і поширюється трансформуючись з економіки, що споживає ресурси в економіку, яка створює ресурси. Серед вчених і практиків не існує єдиного підходу до визначення поняття цифрової економіки. Зміст поняття "цифрова економіка" чітко не визначено. Вчені і дослідники визначають теоретичні аспекти цифрової економіки, як нового етапу господарських відносин інтегрованої взаємодії реальної і віртуальної складових виробничих відносин. Використання цифрових технологій в новій економіці буде розширюватися, а безпосередню участь людини у виробництві зменшуватиметься.

У новій економіці працюють нові механізми ринкової конкуренції. В глобальній економіці знання, і майбутнє в ній матимуть ті, хто зможе перетворити в товар знання і наукові відкриття. Інновації, адаптація і використання нових технологій - основа зростання національної і світової економіки [11].

На думку Організації економічного співробітництва і розвитку, цифрова економіка включає, перш за все, засновані на цифрових технологіях ринки, які стимулюють і полегшують торгівлю товарами і надання послуг, проте це поняття даними ринками не обмежується, оскільки цифровізація впливає на суспільство і економіку в цілому [12]. Цифровізація економіки, несе з собою комплекс змін і зокрема ці зміни супроводжуються суттєвим зростанням цифрової нерівності, що представляє собою обмежений доступ до цифрових техно- логій, знань, інформації, роботи в цифровому середовищі.

Американський економіст Лоуренс Саммерс стверджував, що виробничі конкурентні переваги мають значення для економіки вчорашнього дня, для сьогоднішньої економіки значення мають глобальні мережі і ефект від масштабу [13]. На аномальність розвитку цифрової економіки звертає увагу американський економіст-кейнсіанець, лауреат Нобелівської премії з економіки Джозеф Стігліц, стверджуючи, що на сьогоднішній день багато секторів економіки не слід розглядати через призму вільної конкуренції, оскільки в них переважною формою конкуренції є олігополія [14].

Одним з елементів формування сучасної економіки $\epsilon$ цифрові платформи. Роль цифрових платформ набула глобального значення і деякі дослідники вказуючи на "революції платформ", визначають цифрову платформу як "бізнес, заснований на створені цінностей шляхом взаємодії між зовнішніми виробниками і споживачами. Він забезпечує відкриту інфрраструктуру для учасників взаємодій і встановлює для них інституційні "правила гри", тобто певні "регуляторні режими" [15].

Сьогодні ринкова влада визначається контролем над великим масивом даних, оскільки компанії накопичують інформацію і відбувається мережевий ефект. Цифрова економіка має різні інформаційно-мережеві ефекти (від інновацій, від мережевої взаємодії, від інтеграції бізнесу), що виникають у результаті впровадження інформаційно-комунікаційних технологій, здійснення електронного бізнесу і взаємодій в глобальних мережах та сприяють зростанню загальної продуктивності в економіці.

При аналізі механізмів отримання доходу в економіці нового технологічного типу Хамід Екбіа і Бонні Нарди звернули увагу, що одним з основних таких механізмів став контроль споживчої поведінки і включення споживачів у створення доданої вартості без адекватної компенсації витраченої праці. Цей механізм дозволяє цифровим платформ отримувати непропорційно високі доходи по відношенню до витраченої праці та інвестицій [16, с. 252].

Цифрові платформи грунтуються на багатогранних мережевих ефектах, які забезпечують значне скорочення трансакційних і виробничих витрат і впливають на оборот товарів. Оборот товарів за допомогою цифрових платфрорм забезпечує домінуюче становище товару на ринку і це може призводити до зловживань та обмеження конкуренції.

Характерною рисою цифровізації економіки $є$ поява сучасних технологій Big Data (Великі Дані). Big Data являють собою важливий економічний актив, який може бути використаний організаціями для отримання конкурентних переваг[17]. Великі Дані мають широкий діапазон розподілу, неорганізовану структуру, великий обсяг і часто надходять в режимі реального часу [18]. Компанія Meta Group в 2001 році охарактеризувала Big Data як: обсяг (volume) - значний фрізичний обсяг; швидкість (velocity) - висока швидкість приросту і необхідність високошвидкісної обробки і отримання результатів; різноманітність (variety) - різні типи даних, які можуть бути як структурованими, так і неструктурованими. Надалі додавалися: veracity - достовірність 
Таблиця 1. Визначення категорій Big Data

\begin{tabular}{|c|c|}
\hline В. Серьогін [21] & $\begin{array}{l}\text { Big Data - це потужна форма інтелектуального аналізу } \\
\text { даних, що спирається на величезні обсяги інформації, } \\
\text { супершвидкісні комп'ютери і новітні аналітичні } \\
\text { методи, здатні виявляти приховані, а часом навіть } \\
\text { несподівані кореляції між фактами і явищами } \\
\text { навколишньої дійсності }\end{array}$ \\
\hline Є. Гнітецький [22] & $\begin{array}{l}\text { Big Data - це сукупність інструментів, націлених на } \\
\text { задоволення потреб сучасних організацій в } \\
\text { перетворенні хаотичної маси даних на інформацію, } \\
\text { придатну для використання в процесі прийняття } \\
\text { рішень }\end{array}$ \\
\hline В. Хаханов [23] & $\begin{array}{l}\text { Big Data - це технологічна культура кіберпростору, } \\
\text { спрямована на формування інфраструктури } \\
\text { кіберфізичної екосистеми планети, що динамічно } \\
\text { розвивається, шляхом метрикосематичної системи } \\
\text { структуризації великих потоків (обсягів) гетерогенних } \\
\text { даних на основі використання інтелектуальних } \\
\text { швидкодіючих спеціалізованих хмарних фільтрів } \\
\text { паралельного моніторингу та матричного аналізу, які } \\
\text { витягуються з інформації для оnline управління } \\
\text { фізичними і віртуальними процесами }\end{array}$ \\
\hline $\begin{array}{l}\text { Міжнародний інститут } \\
\text { McKinsey (MGI) [24] }\end{array}$ & $\begin{array}{l}\text { Big Data - це набір даних, розмір яких виходить за } \\
\text { межі можливостей типового програмного } \\
\text { забезпечення для збору, зберігання, управління і } \\
\text { аналізу баз даних }\end{array}$ \\
\hline
\end{tabular}

(використовувалася в рекламних матеріалах IBM), viability - життєздатність, value - цінність, variability - мінливість, i visualization - візуалізація. У всіх випадках зазначається, що визначальною характеристикою для великих даних $€$ не тільки їх фрізичний обсяг, але інші категорії, які важливі для уявлення про складності завдання обробки і аналізу даних [19, с. 32-38].

Феномен Big Data досі не досліджений. 3 одного боку, вони втілюють комп'ютерно-інформаційні тренди останніх десятиліть; з іншого - він сам здатний впливати й реально трансформує існуючі уявлення і напрацьовані протягом тривалого часу практики і моделі поведінки як окремих індивідів, так і складних організаційних структур [20, с. 64-72].

Науковці та практики всебічно характеризують і вносять свої корективи в поняття категорії "Big Data" (табл. 1).

Використання Великих Даних відкриває нові можливості для досліджень динаміки макроекономічних змін, сприяє розвитку онлайн-торгівлі, розширює сфери співпраці з економістами для проведення різного роду експериментів, дозволяє уряду і підприємствам швидше реагувати на зміни економічних умов [25]. Отже, з розвитком технологій інтелектуального аналізу даних, компанії можуть пропонувати рішення для споживачів під їх індивідуальні потреби, забезпечуючи при цьому зворотний зв'язок. Бізнес-література дає підстави вважати, що Big Data відіграють все більш важливу роль в конкуренції. Використання Big Data стає основою конкуренції для існуючих компаній, конкуренти, які не зможуть розвивати свої можливості в цьому напрямі, залишиться позаду. Незважаючи на те, що "Big Data" відноситься до точних наук, цифрового середовища і сорери інформаційних технологій, термін не має чіткого визначення.

Завдяки можливостям збору і обробки великих даних, бізнес може фрормувати власну аналітичну інфрормацію, отримувати інформацію з інших баз даних і на основі цього формувати базу даних користувачів. Це дозволяє не тільки диференціювати ціни, а й цілеспрямовано розсилати рекламні матеріали для впливу на поведінку споживача. При цьому втрачається контроль над персональними даними та конфіденційністю. Порушення антимонопольного законодавства може виражатися в фрормі недобросовісного використання даних про споживачів з метою встановлення різних цін. Збір персональних даних не обов'язково погіршує становище споживачів, оскільки дозволяє компаніям поліпшувати якість продукції та ефективно розподіляти споживачів на групи. Антимонопольне регулювання Big Data обумовлено тим, наскільки їх наявність або передача третій особі впливатимуть на ринок і конкурентне середовище.

Основні дискусії щодо антимонопольного регулювання цифрового середовища йдуть, в основному, серед зарубіжних вчених, дослідників і фахівців. На основі цілого ряду антимонопольних розслідувань, в світі розгортаються напружені дискусії щодо підходів і методів антимонопольного регулювання інформаційних технологій які стрімко змінюються і розвиваються. Цифррова економіка сьогодні характеризується монополією і високою концентрацією, а рівень монополізації ринків і ринкової влади цифрових монополій досяг аномальних розмірів. Журнал "The Economist" акцентує увагу, що світова економіка проходить вищу ступінь концентрації капіталу [26]. Поширення домінування Apple, Google, Facebook i Amazon та їх негативний вплив на конкуренцію і споживачів, спонукає уряди всіх країн активніше застосовувати заходи антимонопольної політики для регулювання ринків цифррової економіки [27]. Apple i Google контролюють операційну систему мобільних телефонів та ключові програми на цій платформі; Amazon контролює найбільшу торгову платформу в Інтернеті; Facebook контролює найбільшу платфрорму соціальної мережі. Через їх провідні платорорми проходить значний обсяг і різноманітний потік персональних даних. Антимонопольні органи провідних країн світу провели ряд розслідувань, спрямованих на усунення абсолютної монополії і захисту конкуренції. В липні 2017 р. Європейська комісія висунула американської транснаціональної корпорації Google Inc. штраф у розмірі 2,42 млрд 
євро за порушення правил антимонопольного законодавства Європейського Союзу [28]. Європейський комісар з питань конкуренції Маргрет Вестагер пояснила, що Google незаконно просував свій сервіс електронної комерції в пошукових результатах і занижував пошуковий рейтинг аналогічних програм конкурентів.

У липні 2018 Європейська комісія знову оштрафувала інтернет-гігант Google на 4,38 млрд євро за зловживання домінуючим становищем на ринку пошукових систем [29]. Google використовував Android, щоб зміцнити провідні позиції своєї пошукової системи на ринку при цьому конкуренти втратили можливість бути конкурентоспроможними, а користувачі втратили переваги ефективної конкуренції. Зауважимо, що монополія і домінуючі позиції на ринку не заборонені, адже вони є результатом ефективної комерційної стратегії, однак, для таких учасників ринку вводиться ряд заборон, які дозволені для дрібних гравців.

Використання компаніями передових технологій дозволяє нав'язувати споживачам неправомірні умови, розширювати ринкову владу, підвищувати ціни і закривати ринки для потенційних конкурентів. Враховуючи тенденції та стрімкий розвиток цифрової економіки, держава має швидко та ефективно реагувати на сучасні виклики. Важливою $є$ стабілізаційна роль держави в економіці, втручання якої має приймати форми автоматичного стабілізатора, який забезпечує збалансоване регулювання економічних процесів на основі розроблення нової парадигми розкриття економічних явищ та процесів [30, с. 93-105]. Антимонопольна політика держави, з огляду на сучасні реалії і можливості цифрової економіки, має сприяти розвитку конкурентних ринків, де переважають ефективність та інновації і запобігати економічної концентрації, що призведе до зловживань ринковою владою.

Знання про Великі Дані може стати важливим джерелом ринкової влади, особливо коли такі дані можуть використовуватися як бар'єри. Швидкість придбання і експлуатація особистих даних допомагає компаніям отримувати значну перевагу і ринкову владу. Крім того, в умовах виробництва інформаційних продуктів, визначення витрат на основі ціни неприйнятні, оскільки граничні витрати на одиницю товару наближаються до нуля. Багато товарів і послуг, запропонованих на ринках електронної комерції, мають нульову ціну, тобто можна отримати товар або послугу без здійснення платежу, але це не означитиме безкоштовно, адже на цьому ринку гроші не єдиний товар, який цінний для обміну. Конкурентний процес нової економіки $є$ динамічним і універсальним, на відміну від фозичних ринків. В умовах цифррової економіки маємо принципову різницю щодо захисту економічної конкуренції в порівнянні з фрізичними ринками.

\section{ВИСНОВКИ}

Цифрова економіка - це фрактор росту і забезпечення конкурентоспроможності інноваційного розвитку. Держава повинна всебічно сприяти розвитку цифрової економіки та формувати новий технологічний устрій для забезпечення конкурентних переваг з огляду на світові тенденції антимонопольного регулювання в умовах цифрровізації. Виходячи з особливостей циф- рової економіки, фрірми часто конкурують за ринок замість того, щоб конкурувати на ринку. Концентрація Великих Даних в руках невеликої кількості учасників збільшує їх переваги на ринку і з ними вже важко конкурувати іншим учасникам.

Антимонопольне регулювання має обмежувати економічний розвиток компаній які мають значну ринкову владу і переваги перед іншими учасниками. Застосування типових антимонопольних підходів, які використовуються на традиційних ринках для аналізу цифрового середовища нової економіки, неприйнятно. Внаслідок прискорення технологічного розвитку, нові ринки дуже швидко змінюються, в таких умовах інструменти антимонопольних органів втрачають свою дію.

Правові інститути в умовах цифрової економіки вимагають значних змін, оскільки вони не пристосовані до сучасної економіки, побудованої на цифрових мережах і нездатні регулювати інтереси різних учасників ринку, надаючи капіталу широкі можливості по вилученню доданої вартості з людської праці, стимулюючи зростання монополізації цифрових платфрорм; тому нагальним постає вирішення проблем антимонопольного регулювання в зв'язку зі зростаючою монополізацією високотехнологічного сектора.

\section{Література:}

1. Економічні теорії в системі наукових економічних знань: навчальний посібник. - 2-ге вид. перероб. та доп. / Н.П. Мацелюх, І.А. Максименко, Круш П.В., Мартиненко В.В., М.М. Теліщук та ін. - К.: Видаництво "Центр учбової літератури", 2016. - 226 с.

2. Цисррова економіка. - Режим доступу: https:/ /uk.wikipedia.org/wiki / Цифрова_економіка

3. Tapscott, Don (1997). The digital economy: promise and peril in the age of networked intelligence. - New York: McGraw-Hill.

4. Negroponte N. Being Digital / N. Negroponte. NY: Knopf, 1995. - 256 p.

5. Mesenbourg T.L. (2001). Measuring the Digital Economy. U.S. Bureau of the Census.

6. Фіщук В. Цифрова економіка - це реально / В. Фіщук [Електронний ресурс]. - Режим доступу : https:/ /biz.nv.ua/ukr/experts/fichuk/tsifrova-ekonomikatse-realno-1001102.html

7. Жукова Л.М. Цифрова економіка як об'єкт державного регулювання [Електронний ресурс] / Л.М. Жукова / / Економічний вісник Запорізької державної інженерної академії. - 2017. - Вип. 5(1). - С. 7-11. - Режим доступу: http://nbuv.gov.ua/UJRN/ evzdia_2017_5(1)_3

8. Апалькова В.В. Концепція розвитку цифрової економіки в Євросоюзі та перспективи України / В. В. Апалькова / / Вісник Дніпропетровського університету. Серія : Менеджмент інновацій. - 2015. - Т. 23, Вип. 4. - С. 9-18. - Режим доступу: http://nbuv.gov.ua/ UJRN/vdumi_2015_23_4_4

9. Коляденко С.В. Цифррова економіка: передумови та етапи становлення в Україні і у світі / С.В. Коляденко // Економіка. Фінанси. Менеджмент: актуальні питання науки і практики. - 2016. - № 6. - С. 105112. - Режим доступу: http://nbuv.gov.ua/UJRN/ efmapnp_2016_6_11 
10. Кіт Л. З. Еволюція мережевої економіки / Л. 3. Кіт / / Вісник Хмельницького національного університету. Економічні науки. - 2014. - № 3 (2). - С. 187 194. - Режимv доступу: http://nbuv.gov.ua/UJRN/ Vchnu_ekon_2014_3\%282\%29 42

11. Maskus K. Private Rights and Public Problems: The Global Economics of Intellectual Property in the 21st Century. Peterson Inst. for Intern. Economics, 2012. Режимv доступу: https://books.google.com.ua/ books?id=Pm9CCMg EYTYC\&pg=PA338\&lpg=PA338\&dq=Maskus+K.+Private+Rights+and+Public+Problems\&source $=$ bl\&ots $=$ LNuLg6e8hp\&sig=yRoeH24NdHYiyVYWSXgAvVNLSt8\&hl=ru\&sa=X\&ved=2ahUKEwiFjW6s9_eAhVqpYsKHVHcA24Q6AEwCHoECAIQAQ \#v=onepage $\& q=$ Maskus $\% 20 \mathrm{~K}$.$\% 20$ Private $\% 20$ Rights $\% 20$ and $\% 20$ Public $\% 20$ Problems\&f=false

12. Competition Committee of Organisation for Economic Cooperation and Development: The Digital Economy. 2012 / / Competition Law \& Policy. 2013. Feb. 7. - Режимv доступу: URL: http://www.oecd.org/ daficompetitionIThe-DigitalEcono- my-2012.pdf

13. Summers L.H. The New Wealth of Nations: remarks by treasury secretary Lawrence $H$. Summers at Hambrecht \& Quist technology conference, San Francisco, CA. U.S. Department of the Treasury, 10 May 2000

14. Stiglitz J. Monopoly's New Era // Project Syndicate. 2006. Мау 13. Режим доступу: URL:https:// www.project-syndicate.org/commentary/highmonopoly-profits-per-sist-in-markets-by-joseph-e-stiglitz-2016-05

15. Ляшенко В.І. Цифрова модернізація економіки України як можливість проривного розвитку: монографрія / В.І. Ляшенко, О.С. Вишневський; НАН України, Ін-т економіки пром-сті. - К., 2018. - 252 с.

16. Hamid R. Ekbia and Bonnie A. Nardi Heteromation, and Other Stories of Computing and Capitalism / / Режим доступу: https://mitpress.mit.edu/books/ heteromation-and-other-stories-computing-andcapitalism

17. No Mistake About It: The Important Role of Antitrust in the Era of Big Data // Режим доступy: https:// www.americanbar.org/content/dam/aba/publishing / antitrust_source/apr15_grunes_4_22f.authcheckdam.pdf

18. Єршова О.Л. Великі дані (Big Data) і модернізація національних систем офіційної статистики [Електронний ресурс] / О.Л. Єршова, Т.В. Томашевська // Прикладна статистика: проблеми теорії та практики. 2016. - Вип. 18-19. - С. 32-38. - Режим доступу: http://nbuv.gov.ua/UJRN/Pspttp_2016_18-19_7

19. Большие данные. - Режим доступу: https:// ru.wikipedia.org/wiki/Большие_данные

20. Задорожна Р.П. Big data - новий інформаційний феномен цифрової епохи [Електронний ресурс] / Р. П. Задорожна / / Економіка та управління АПК. 2016. - № 1-2. - С. 64-72. - Режим доступу: http:/ /nbuv.gov.ua/UJRN/ecupapk_2016_1-2_12

21. Серёгин B.A."Big data": новая угроза для прайвеси в условиях инфрормационного общества [Електронний ресурс] / В.А. Серёгин // Науковий вісник Ужгородського національного університету. Серія: Право. 2015. - Вип. 35 (1.1). - С. 93-97. - Режим доступу: http://nbuv.gov.ua/UJRN/nvuzhpr_2015_35(1)
22. Гнітецький Є.В. Big data в маркетингу: орієнтація на споживача [Електронний ресурс] / Є.В. Гнітецький // Економічний вісник Національного технічного університету України "Київський політехнічний інститут". - 2017. - № 14. - С. 281-285. - Режим доступу: http://nbuv.gov.ua/UJRN/evntukpi_2017_14_45

23. Хаханов В.И. Процессорные структуры для анализа Big Data [Електронний ресурс] / В.И. Хаханов, Е.И. Литвинова, С.В. Чумаченко, И. Емельянов, Бани Амер Тамер / / Радіоелектронні і комп'ютерні системи. - 2016. - № 6. - С. 163-175. - Режим доступу: http://nbuv.gov.ua/UJRN/recs_2016_6_27

24. Big Data: The Next Frontier for Innovation, Competition, and Productivity. Режим доступу: https:// www.mckinsey.com/ /media/McKinsey/Business \% 20Functions/McKinsey \%20Digital/Our\%20Insights / Big $\% 20$ data $\% 20$ The $\% 20$ next $\% 20$ frontier $\% 20$ for $\% 20$ innovation/MGI_big_data_exec_summary.ashx

25. Зибарева О.В. Актуалізація концепції "великі дані" (англ. "Big Data") в умовах поширення інформаційного суспільства [Електронний ресурс] / О.В. Зибарева, І.П. Кравчук. // Економіка. Управління. Інновації. - 2015. - № 1. - Режим доступу: http://nbuv.gov.ua/UJRN/eui_2015_1_15

26. The Rise of Superstars // The Economist: spec. rep. 2016. Sept. 17. URL: Режим доступу: http:// www.economist.com/news/special-report/21707048small-group-giant-companiessome-old-some-newareonce-again-dominating-global

27. How to Tame the Tech Titans / / Ibid. 2018. Jan. 18. Режим доступу: URL: https://www.economist.com/ news/leaders/21735021-dominance-google-facebookand-amazon-bad-consumers-and-competition-how-tame

28. European Commission. Press Release Database. Режим доступу: http://europa.eu/rapid/pressrelease_IP-17-1784_en.htm

29. European Commission. Press Release Database. Режим доступу: http://europa.eu/rapid/press-release_IP-17-1784_en.htm

30. Уманців Ю.М. Інституційна обумовленість економічних функцій держави [Електронний ресурс] / Ю.М. Уманців, О.О. Кравчук // Економічна теорія та право. - 2017. - № 4. - С. 93-105. - Режим доступу: http://nbuv.gov.ua/UJRN/Vnyua_etp_2017_4_9

\section{References:}

1. Matseliukh, N.P. Maksymenko, I.A. Krush, P.V. Martynenko, V.V. and Telischuk, M.M. (2016), Ekonomichni teorii v systemi naukovykh ekonomichnykh znan' [Economic theories in the system of scientific economic knowledge], Vydanytstvo "Tsentr uchbovoi literatury", Kyiv, Ukraine.

2. wikipedia (2018), "Digital economy", available at: https://en.wikipedia.org/wiki/Digital_economy (Accessed 15 Nov 2018).

3. Tapscott, D. (1997), The digital economy: promise and peril in the age of networked intelligence, McGrawHill, New York, USA.

4. Negroponte, N. (1995), Being Digital, Knopf, New York, USA.

5. Mesenbourg, T.L. (2001), Measuring the Digital Economy, U.S. Bureau of the Census, Suitland, USA. 
6. Fischuk, V. (2017), "The digital economy is real", available at: https://biz.nv.ua/ukr/experts/fichuk/ tsifrova-ekonomika-tse-realno-1001102.html (Accessed 15 Nov 2018).

7. Zhukova, L.M. (2017), "Digital economy as an object of state regulation", Ekonomichnyj visnyk Zaporiz'koi derzhavnoi inzhenernoi akademii, vol. 5 (1), pp. 7-11.

8. Apal'kova, V.V. (2015), "The concept of the development of the digital economy in the European Union and the prospects of Ukraine", Visnyk Dnipropetrovs'koho universytetu. Seriia: Menedzhment innovatsij, vol. 23, vyp. 4, pp. $9-18$.

9. Koliadenko, S.V. (2016), "Digital economy: preconditions and stages of formation in Ukraine and in the world", Ekonomika. Finansy. Menedzhment: aktual'ni pytannia nauky i praktyky, vol. 6, pp. 105-112.

10. Kit, L.Z. (2014), "Evolution of the network economy", Visnyk Khmel'nyts'koho natsional'noho universytetu. Ekonomichni nauky, vol. 3 (2), pp. 187-194.

11. Maskus, K. (2012), "Private Rights and Public Problems: The Global Economics of Intellectual Property in the 21st Century", Peterson Inst. for Intern. Economics, available at: https://books.google.com.ua/books?$\mathrm{id}=\mathrm{Pm}$ 9CCMgEYTYC \&pg=PA338\&lpg=PA338\&dq= Maskus+K. +Private+Rights +and+Public + Problems\&source=bl\&ots $=$ LNuLg6e8hp\&sig= yRoeH24NdHYiyVYWSXgAvVNLSt8\&hl=ru\&sa=$X \& v e d=2$ ahUKEwiFjW6s9_eAhVqpYsKHVHcA24Q6AEwCHoECAIQAQ\#v=onepage \&q=Maskus$\% 20 \mathrm{~K} . \% 20 \mathrm{Private} \% 20 \mathrm{Rights} \% 20$ and \% 20Public \% 20Problems\&f=false (Accessed 15 Nov 2018).

12. Competition Committee of Organisation for Economic Cooperation and Development (2012), "The Digital Economy", available at: http://www.oecd.org/ daficompetitionIThe-DigitalEcono-my-2012.pdf (Accessed 15 Nov 2018).

13. Summers, L.H. (2000), The New Wealth of Nations: remarks by treasury secretary Lawrence $H$. Summers at Hambrecht \& Quist technology conference, Department of the Treasury, San Francisco, CA. U.S.

14. Stiglitz, J. (2006), "Monopoly's New Era", Project Syndicate, available at: https://www.project-syndicate.org/commentary/high-monopoly-profits-per-sistin-markets-by-joseph-e--stiglitz-2016-05 (Accessed 15 Nov 2018).

15. Liashenko, V.I. and Vyshnevs'kyj, O.S. (2018), Tsyfrova modernizatsiia ekonomiky Ukrainy iak mozhlyvist' proryvnoho rozvytku [Digital modernization of the Ukrainian economy as an opportunity for breakthrough development], NAN Ukrainy, In-t ekonomiky prom-sti, Kyiv, Ukraine.

16. Ekbia, H.R. and Nardi, B.A. (2017), "Heteromation, and Other Stories of Computing and Capitalism", available at: https://mitpress.mit.edu/books/heteromation-andother-stories-computing-andcapitalism (Accessed $15 \mathrm{Nov}$ 2018).

17. Grunes, A.P. and Stucke, M.E. (2015), "No Mistake About It: The Important Role of Antitrust in the Era of Big Data", available at: https://www.americanbar.org/ content/dam/aba/publishing/antitrust_source / apr15_grunes_4_22f.authcheckdam.pdf (Accessed 15 Nov 2018).
18. Yershova, O.L. and Tomashevs'ka, T.V. (2016), "Large data (Big Data) and modernization of national official statistics systems", Prykladna statystyka: problemy teorii ta praktyky, vol. $18-19$, pp. $32-38$.

19. wikipedia (2018), "Big Data", available at: https:/ /en.wikipedia.org/wiki/Big_data (Accessed 15 Nov 2018).

20. Zadorozhna, R.P. (2016), "Big data - a new information phenomenon of the digital era", Ekonomika ta upravlinnia APK, vol. 1-2, pp. 64-72.

21. Seriohyn, V.A. (2015), "'Big data": a new threat to privacy in the information society", Naukovyj visnyk Uzhhorods'koho natsional'noho universytetu. Seriia : Pravo, vol. 35 (1.1), pp. 93-97.

22. Hnitets'kyj, Ye.V. (2017), "Big data in marketing: consumer orientation", Ekonomichnyj visnyk Natsional'noho tekhnichnoho universytetu Ukrainy "Kyivs'kyj politekhnichnyj instytut", vol. 14, pp. 281-285.

23. Khakhanov, V.Y. Lytvynova, E.Y. Chumachenko, S.V. Emel'ianov, Y. and Bany, A.T. (2016), "Processor structures for Big Data analysis", Radioelektronni i komp'iuterni systemy, vol. 6, pp. 163-175.

24. McKinsey Global Institute (2011), "Big Data: The Next Frontier for Innovation, Competition, and Productivity", available at: https://www.mckinsey.com/ /media/McKinsey/Business \% 20Functions/ McKinsey \% 20Digital /Our \% 20lnsights / Big \%20 data $\% 20$ The $\% 20$ next $\% 20$ frontier $\% 20$ for $\%$ 20 innovation/MGI_big_data_exec_summary.ashx (Accessed 15 Nov 2018).. Rezhym dostūpu:

25. Zybareva, O.V. and Kravchuk, I.P. (2015), "Actualization of the Big Data (Big Data) concept in the context of the dissemination of the Information Society", Ekonomika. Upravlinnia. Innovatsii, vol. 1, available at: http://nbuv.gov.ua/UJRN/eui_2015_1_15 (Accessed 15 Nov 2018).

26. The Economist (2016), "The Rise of Superstars", available at: http://www.economist.com/news/specialreport/21707048-small-group-giant-companiessome-oldsome-neware-once-again-dominating-global (Accessed 15 Nov 2018).

27. The Economist (2018), "How to Tame the Tech Titans", available at: https://www.economist.com/ news/leaders/21735021-dominance-google-facebookand-amazon-bad-consumers-and-competition-how-tame (Accessed 15 Nov 2018).

28. European Commission (2017), "Antitrust: Commission fines Google $€ 2.42$ billion for abusing dominance as search engine by giving illegal advantage to own comparison shopping service", Press Release Database, available at: http://europa.eu/rapid/pressrelease_IP-17-1784_en.htm (Accessed 15 Nov 2018).

29. European Commission (2017), "Antitrust: Commission fines Google $€ 2.42$ billion for abusing dominance as search engine by giving illegal advantage to own comparison shopping service", Press Release Database, available at: http://europa.eu/rapid/pressrelease_IP-17-1784_en.htm (Accessed 15 Nov 2018).

30. Umantsiv, $\bar{Y}$ u.M. and Kravchuk, O.O. (2017), "Institutional conditionality of economic functions of the state", Ekonomichna teoriia ta pravo, vol. 4, pp. 93-105. Стаття надійшла до редакиії 20.11.2018 p. 